\title{
Investigation of Frequency of Herpes Simplex Virus in Patients with Type 2 Diabetes and Healthy Individuals by PCR and ELISA
}

Masood Ghane (PhD)

Department of Microbiology, Islamic Azad University, Tonekabon Branch, Tonekabon, Iran

Corresponding author: Masood Ghane

Email: Masoodghane@gmail.com Tel: +989111936373

Address: Department of microbiology, Tonekabon branch, Islamic Azad University, Tonekabon, Iran

Received : 33 Apr 2017

Revised: 01 Sep 2017

Accepted: 10 Sep 2017

\section{ABSTRACT}

Background and Objectives: Previous studies have demonstrated the relationship between viral infections and risk of developing type 1 diabetes. The aim of this study was to investigate the frequency of Herpes simplex virus (HSV) in patients with type 2 diabetes and healthy control individuals using PCR and ELISA.

Methods: Blood samples were taken from 180 diabetic patients and 187 healthy controls referred to the Pasteur medical laboratory in Tonekabon, in 2016. Human betaglobin gene was used as internal control to ensure extraction accuracy. Specific primers were used for amplification of the UL30 gene. In addition, level of anti-HSV IgG antibody was measured using a commercial ELISA kit (Euroimmun, Germany).

Results: DNA of HSV was found in the samples of 11 patients (6.1\%) and five healthy controls (2.7\%). In addition, anti-HSV IgG was found in the samples of 117 patients (65\%) and 108 healthy controls (57.75\%). There was a statistically significant relationship between frequency of anti-HSV IgC and diabetes.

Conclusion: Similar to previous studies, the present study demonstrated a relationship between frequency of HSV infection and type 2 diabetes. However, further studies should be performed to eliminate the effect of other risk factors to help clarify the exact role of viral infections in increasing the risk of diabetes.

Keywords: Diabetes, Herpes Simplex Virus, ELISA, PCR. 


\section{INTRODUCTION}

Diabetes refers to a group of metabolic disorders characterized by chronic hyperglycemia. Considering the rising prevalence of diabetes worldwide, it is expected that the disease will remain as one of the main causes of morbidity and mortality (1). Several factors such as genetic susceptibility, obesity, age, high blood pressure, high blood lipids, and several environmental factors are associated with incidence of diabetes (2). Determining the initial environmental factor is not simple because the exposure to the factor might have occurred many years before development of diabetes. A possible environmental factor is infection with different families of viruses (3-10). Herpesviridae is a large family of viruses that are pathogenic to humans. Identifying characteristics of these viruses, helps clarify their ability in causing latent infections (11). Herpes simplex virus (HSV) is widely distributed throughout the world. These viruses have various hosts and are capable of reproducing in different types of cells. HSV can cause several diseases, including chronic gingivostomatitis, keratoconjunctivitis, encephalitis, genital disease, neonatal infection, and latent infection of neurons (11).

The aim of this study was to investigate prevalence of HSV in patients with type 2 diabetes and healthy controls using polymerase chain reaction (PCR) and enzymelinked immunosorbent assay (ELISA).

\section{MATERIAL AND METHODS}

This randomized cross-sectional study was conducted on 180 diabetic patients and 187 healthy blood donors (control group) referred to the Pasteur medical laboratory in Tonekabon, in 2016. Diabetes was confirmed in the participants via laboratory testing and by an internal medicine physician. Blood samples were taken from the participants after obtaining written consent.

Effect of any underlying disorder including immunodeficiency, allergy, cancer, etc. was eliminated. After recording demographic information of the participants, $5 \mathrm{ml}$ blood samples were taken and transferred to tubes containing EDTA. After centrifuging the samples, $50 \mu \mathrm{l}$ of plasma was transferred to another sterile tube in order to perform ELISA. The remaining samples were stored at $-20{ }^{\circ} \mathrm{C}$ until DNA extraction process.
DNA extraction was carried out using commercial kits (Qiagene, Lot No: 11872534, Cat No: 51306) according to the manufacturer's instructions. Purity of the extracted DNA was analyzed by assessing absorbance at 260 and $280 \mathrm{~nm}$ using a BioPhotometer (Eppendorf, Germany).

Human beta-globin gene was co-amplified with the target fragment, as an internal amplification control, using the following primers: Forward: 5'-TCC AAC ATC AAC ATC TTG GT-3' and Reverse: 5'- TCC CCC AAA TTC TAA GCA GA-3' (12).

The following specific primers were used for amplification of the UL3O gene: Forward: 5'CAG TAC GGC CCC GAG TTC GTG A -3' and Reverse: 5'- GTA GTA GGT GCG GGT GAT GTT -3' (13). The primers were synthesized by TAG Copenhagen (Denmark).

PCR was performed in a $25 \mu 1$ reaction mixture containing $13 \mu \mathrm{l}$ of molecular biology-grade water (Sigma Aldrich Company LTD., USA), $2.5 \mu$ of $10 \times$ PCR buffer (Promega, USA), $1 \mu \mathrm{l}$ of forward and reverse primers, $1 \mu \mathrm{l}$ of $10 \mathrm{mM}$ dNTPs (Promega, USA), $0.5 \mu$ l of smart taq DNA polymerase (Promega, USA), $1 \mu \mathrm{l}$ of $50 \mathrm{mM} \mathrm{MgCl}_{2}$ (Promega, USA), and $5 \mu \mathrm{l}$ of DNA template. The negative control contained all PCR reagents and $5 \mu \mathrm{l}$ of water instead of the DNA template.

A small aliquot of PCR products was electrophoresed on $1.5 \%(\mathrm{w} / \mathrm{v})$ agarose gel stained with ethidium bromide at $80 \mathrm{~V}$ for 60 min. Results of the electrophoresis were visualized and photographed under a UVtransilluminator (UV doc, England).

ELISA was performed to measure the level of anti-HSV IgG using commercial kits (Euroimmun, Germany), according to the manufacturer's instructions. First, samples and the ELISA kit were placed at room temperature for 30 minutes. A 1:10 dilution of plasma and dilution buffer was prepared. Then, $100 \mu \mathrm{l}$ of the standards 1,2 and 3, as well as positive and negative controls and plasma samples were poured into the microplate. The plate was incubated at room temperature for 30 minutes. Each well was washed three times with $450 \mu$ of buffer solution. Then, $100 \mu \mathrm{l}$ of enzyme conjugate were added to each well. The plate was incubated at room temperature for 30 minutes and the washing was repeated. Next, $100 \mu \mathrm{l}$ of 
the substrate/choromogen solution was added to each well.

After 15 minutes of incubation in darkness at room temperature, $100 \mu 1$ of stop solution was added to each well. Finally, absorbance was measured at $450 \mathrm{~nm}$ and $630 \mathrm{~nm}$ in an ELISA microplate reader (Germany).

Data analysis was done in SPSS (version 17). Chi square test was used to compare the results at significance of 0.05 .

Table 1- PCR conditions for amplification of human beta globin and UL30genes

\begin{tabular}{|c|c|c|c|c|}
\hline \multirow{2}{*}{ Steps } & \multicolumn{2}{|c|}{ Human beta globin gene } & \multicolumn{2}{|l|}{ UL30 gene } \\
\hline & Temperature and duration & Cycle & Temperature and duration & Cycle \\
\hline Initial denaturation & $95^{\circ} \mathrm{C}-5 \min$ & 1 & $94^{\circ} \mathrm{C}-10 \mathrm{~min}$ & 1 \\
\hline Denaturation & $95^{\circ} \mathrm{C}-45 \mathrm{sec}$ & 35 & $94^{\circ} \mathrm{C}-60 \mathrm{sec}$ & 35 \\
\hline Annealing & $54^{\circ} \mathrm{C}-30 \mathrm{sec}$ & & $63^{\circ} \mathrm{C}-30 \mathrm{sec}$ & \\
\hline Extension & $72^{\circ} \mathrm{C}$ - $30 \mathrm{sec}$ & & $72^{\circ} \mathrm{C}-50 \mathrm{sec}$ & \\
\hline Final Extension & $72^{\circ} \mathrm{C}-10 \mathrm{~min}$ & 1 & $72^{\circ} \mathrm{C}-10 \mathrm{~min}$ & 1 \\
\hline
\end{tabular}

\section{RESULTS}

Detection of the $122 \mathrm{bp}$ and $480 \mathrm{bp}$ fragments indicated presence of the Human beta globin gene and $U L 30$ gene, respectively (Figures 1 and 2). All samples were positive for beta globin gene, which shows the accuracy of DNA extraction.

The samples of 11 diabetic patients $(6.1 \%)$ and five healthy controls $(2.7 \%)$ contained the HSV DNA. Table 1 shows the frequency distribution of HSV DNA based on gender and age group. The results showed that $4.8 \%$ of men and $7.3 \%$ of women in the diabetic group and $1.1 \%$ of men and $4.1 \%$ of women in the control group had been infected with HSV. Moreover, $10 \%$ of the patients under 40 years, $6 \%$ of the patients aged 40-60 years, and $2.5 \%$ of the patients older than 60 years were positive for infection with the virus. Furthermore, $4.5 \%$ of the healthy individuals aged under 40 years and $2.8 \%$ of the controls aged 40-60 years were positive for infection with the virus.

\section{Figure 1- Gel electrophoresis of Human beta-globin amplification products on $1.5 \%$ agarose gel stained with ethidium bromide. The 122-bp band (columns 1 and 2) indicates the presence of beta globin gene. Column M: 100 bp DNA ladder, Column 3: Negative control.}

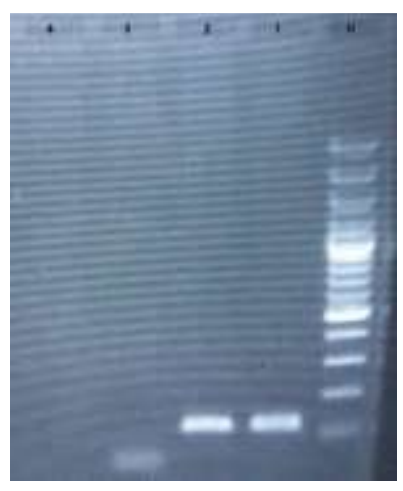

Figure 2- Gel electrophoresis of HSV gene amplification products on $1.5 \%$ agarose gel stained with ethidium bromide. Detection of the 480 bp band indicates the presence of HSV DNA. Column M: 100 bp DNA ladder, Column 1-4: amplified HSV DNA, Column 5: Negative control.

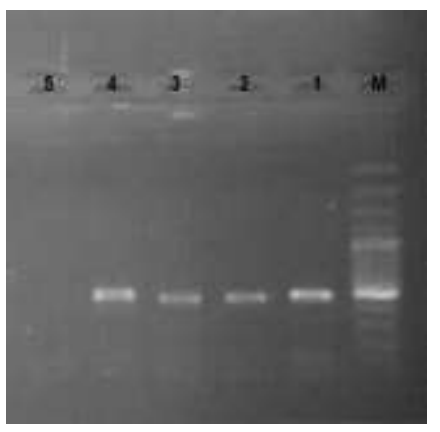


Table 1- Frequency distribution of HSV DNA based on gender and age group

\begin{tabular}{|c|c|c|c|c|c|c|c|c|c|}
\hline \multirow{2}{*}{$\begin{array}{c}\text { Demographic } \\
\text { variable }\end{array}$} & \multirow[t]{2}{*}{ Status } & \multicolumn{4}{|c|}{ Patients group } & \multicolumn{4}{|c|}{ Control group } \\
\hline & & $\begin{array}{l}\text { No. } \\
\text { Tested }\end{array}$ & $\begin{array}{c}\text { No. } \\
\text { HSV } \\
\text { Positive }\end{array}$ & $(\%)$ & P Value & $\begin{array}{l}\text { No. } \\
\text { Tested }\end{array}$ & $\begin{array}{l}\text { No. HSV } \\
\text { Positive }\end{array}$ & $(\%)$ & P Value \\
\hline \multirow[t]{2}{*}{ Sex } & Men & 84 & 4 & $4.8 \%$ & 0.48 & 90 & 1 & $1.1 \%$ & 0.37 \\
\hline & Women & 96 & 7 & $7.3 \%$ & & 97 & 4 & $4.1 \%$ & \\
\hline \multirow[t]{3}{*}{ Age (years) } & $<40$ & 40 & 4 & $10 \%$ & 0.393 & 45 & 2 & $4.5 \%$ & 0.21 \\
\hline & $40-60$ & 100 & 6 & $6 \%$ & & 110 & 3 & $2.8 \%$ & \\
\hline & $>60$ & 40 & 1 & $2.5 \%$ & & 32 & $\mathbf{0}$ & $\mathbf{0}$ & \\
\hline
\end{tabular}

Table 2- Frequency distribution of anti-HSV antibody based on gender and age

\begin{tabular}{|c|c|c|c|c|c|c|c|c|c|}
\hline \multirow{2}{*}{$\begin{array}{c}\text { Demographic } \\
\text { variable }\end{array}$} & \multirow[t]{2}{*}{ Status } & \multicolumn{4}{|c|}{ Patients group } & \multicolumn{4}{|c|}{ Control group } \\
\hline & & $\begin{array}{c}\text { No. } \\
\text { Tested }\end{array}$ & $\begin{array}{l}\text { No. HSV } \\
\text { Positive }\end{array}$ & $(\%)$ & P Value & No. Tested & $\begin{array}{l}\text { No. HSV } \\
\text { Positive }\end{array}$ & $(\%)$ & P Value \\
\hline \multirow[t]{2}{*}{ Sex } & Men & 84 & 43 & $51.2 \%$ & 0.001 & 90 & 32 & $35.5 \%$ & 0.001 \\
\hline & Women & 96 & 74 & $77 \%$ & & 97 & 76 & $78.3 \%$ & \\
\hline \multirow[t]{3}{*}{ Age (years) } & $<40$ & 40 & 35 & $87.5 \%$ & 0.001 & 45 & 29 & $64.5 \%$ & 0.001 \\
\hline & $40-60$ & 100 & 74 & $74 \%$ & & 110 & 74 & $67.3 \%$ & \\
\hline & $>60$ & 40 & 8 & $20 \%$ & & 32 & 5 & $15.6 \%$ & \\
\hline
\end{tabular}

There was no significant correlation between frequency of HSV and demographic variables in the participants of both groups.

Based on the results obtained from the ELISA test, 117 patients $(65 \%)$ and 108 healthy controls $(57.75 \%)$ had the anti-virus specific antibody. In addition, $51.2 \%$ of men and $77 \%$ of women in the patient group as well as $35.5 \%$ of men and $78.3 \%$ of women in the control group had the anti-virus specific antibody. Moreover, the samples of $87.5 \%$ of the patients aged under 40 years, $74 \%$ of the patients aged between 40 and 60 years and $20 \%$ of the patients older than 60 years were positive for infection with this virus. As shown in Table 2, there was a significant relationship between frequency of anti-HSV antibody with gender and age of the participants.

\section{DISCUSSION}

The prevalence of diabetes has increased notably in the past few decades. It is expected that the disease will affect more than 438 million individuals by 2030 (14). In Iran, diabetes is the most prevalent non-contagious disease with prevalence of 5.5\% (15). Several studies have investigated the frequency of viral infections among diabetic patients and healthy individuals. The results of these studies confirmed the potential role of infection with some viruses including Parvovirus, Coxsackie B, Adenovirus, Rubella, Cytomegalovirus, and HSV in development of diabetes (1-5).
The frequency of HSV in diabetics and healthy individuals was determined in this study. The prevalence of the virus in diabetics and healthy controls was $6.1 \%$ and $2.7 \%$, respectively. Frequency of anti-HSV IgG in diabetic patients and healthy controls was $65 \%$ and $57.75 \%$, respectively. In line with our study, a study conducted by Sun et al. showed that the frequency of HSV DNA and $\operatorname{IgG}$ against the virus was higher in type 2 diabetes patients compared with healthy controls (16). A study by Pak et al. confirmed the relationship between infection with human herpesvirus-5 and the risk of developing type 1 diabetes (17). Several studies have reported the higher frequency of $\mathrm{HSV}$ and anti-HSV $\operatorname{IgG}$ in patients with type two diabetes compared with healthy individuals. These results suggest a relationship between infection with the virus and the risk of developing type 2 diabetes. Some studies indicated that infection with HSV might increase susceptibility to diabetes via damage to the pancreatic cells (4). Studies of Jia and Guo, Nordal et al., Roberts and Cech, and Chen et al. demonstrated that infection with human herpesvirus-5 increases the risk of developing diabetes via direct pancreatic cell damage and disruption of insulin release from pancreatic beta cells (18$21)$. Detecting the genetic material of the virus confirmed presence of the virus in diabetic patients. Therefore, preventing infection with the virus could help reduce the risk of 
developing type 2 diabetes. On the other hand, diabetic patients are more susceptible to viral infections because of their weakened immune system (21).

\section{CONCLUSION}

Similar to previous studies, the present study demonstrated the relationship between frequency of HSV infection and type 2 diabetes. However, further studies should be performed to eliminate the effect of other risk factors to help clarify the exact role of viral infections in increasing the risk of diabetes.

\section{REFERENCES}

1. Precechtelova J, Borsanyiova M, Sarmirova S, and Bopegamage S. Type I Diabetes Mellitus: Genetic Factors and Presumptive Enteroviral Etiology or Protection. Journal of Pathogens. 2014; 738: 512-521.

2. Qiu YH, Deng FY, Li MJ, Lei SF. Identification of novel risk genes associated with type 1 diabetes mellitus using a genome-wide gene-based association analysis. Journal of Diabetes Investigation. 2014; 13(2): 435-439. doi: 10.1111/jdi.12228.

3. Sadeharju K, Hämäläinen AM, Knip M, Lönnrot M, Koskela P, Virtanen SM, et al. Enterovirus infections as a risk factor for type I diabetes: virus analyses in a dietary intervention trial. Clinical and Experimental Immunology. 2003; 132(2): 271-277.

4. Lönnrot M, Salminen K, Knip M, Savola K, Kulmala P, Leinikki $\mathrm{P}$, et al. Enterovirus RNA in serum is a risk factor for beta-cell autoimmunity and clinical type 1 diabetes: a prospective study. Childhood Diabetes in Finland (DiMe) Study Group. Journal of Medical Virology. 2000; 61(2): 214-220.

5. Oikarinen S, Tauriainen S, Hober D, Lucas B, Vazeou A, Sioofy-Khojine A, et al. Virus antibody survey in different european populations indicates risk association between coxsackievirus BI and type 1 diabetes. Diabetes. 2014; 63(2): 655-662.

6. Ginsberg-Fellner F, Witt ME, Fedun B, Taub F, Dobersen MJ, McEvoy RC, et al. Diabetes Mellitus and Autoimmunity in Patients with the Congenital Rubella Syndrome. Reviews of Infectious Diseases. 1995; 7(1): S170-S176.

7. Honeyman MC, Coulson BS, Stone NL, Gellert SA, Goldwater PN, Steele CE, et al. Association between rotavirus infection and pancreatic islet autoimmunity in children at risk of developing type 1 diabetes. Diabetes. 2000; 49(8): 1319-1324.

8. Hyöty H, Leinikki P, Reunanen A, Ilonen J, Surcel HM, Rilva A, et al. Mumps infections in the etiology of type 1 (insulin-dependent) diabetes. Diabetes Res. 1988; 9(3): 111-116.

9. Aarnisalo J, Veijola R, Vainionpää R, Simell O, Knip M, and Ilonen J. Cytomegalovirus infection in early infancy: risk of induction and progression of autoimmunity associated with type 1 diabetes. Diabetologia. 2008; 51(5): 769-772. doi: 10.1007/s00125-008-0945-8.

10. Nassaji-Zavareh M, Taheri R, Ghorbani R, Aminian M. Undiagnosed Diabetes Mellitus in Patients with Herpes Zoster. Indian J Dermatol. 2008; 53(3): 119-121.

11. Ryan KJ, Ray CG. Sherris Medical Microbiology. $4^{\text {th }}$ ed. McGraw Hill; 2004.

\section{ACKNOWLEDGMENTS}

This study was derived from a research project supported and approved by the Islamic Azad University of Tonekabon (project no. 3237). The author would like to thank the university's deputy of research and technology and Dr. Jamshid Kazemi and staff of the Pasteur medical diagnostic laboratory of Tonekabon.

\section{CONFLICT OF INTEREST}

There is no conflict of interest.

12. Najafi S, Ghane M, Yousefzadeh-Chabok S, Amiri M. The High Prevalence of the Varicella Zoster Virus in Patients with Relapsing-Remitting Multiple Sclerosis: A Case-Control Study in the North of Iran. Jundishapur J Microbiol. 2016; 9(3): 34158. doi: $10.5812 / \mathrm{jjm} .34158$.

13. Zaravinos A, Bizakis J, Spandidos A. Prevalence of papilloma virus and Human Herpes virus Type 1-7 in Human Nasal Polyposis. Journal of Medical Virology. 2009; 81(9):1613-1618.

14. International Diabetes Federation IDF Diabetes Atlas. Epidemiology and Mobidity. In: International Diabetes Federation. Available from http://www.idf.org/. Accessed on 1 March 2011.

15. Azimi-Nezhad M, Ghayour-Mobarhan M, Parizadeh MR, Safarian M, Esmaeili H, Parizadeh $\mathrm{SM}$, et al. Prevalence of type 2 diabetes mellitus in Iran and its relationship with gender, urbanisation, education, marital status and occupation. Singapore Med J. 2008; 49(7): 571-6.

16. Sun Y, Pei A, Wu Y, Yang Y. HSV-1 infection with Type 2 diabetes. Diabetes care. 2005; 13(2): 435436.

17. Pak CY, Mcarthur RG, Eun, HM, Yoon JW. Association of cytomegalovirus infection with autoimmune type 1 diabetes. Lancet. 1988; 12(4): 134139.

18. Guo T, Jia H. Epidemilogic study of cytomegalo virus infection in patients with diabetes mellitus. Zhonghua Liu Xing Bing Xue Za Zhi. 1998; 19(5): 274-276.

19. Nordal KP, Jenssen T, Hjelmesaeth J, Sagedal S, Hartmann A, et al. Asymptomatic cytomegalovirus infection is associated increased risk of new-onset diabetes mellitus and impaired insulin release after renal. Diabetologica. 2004; 47(9): 1550-1556.

20. Roberts BW, Cech I. Association of type 2 diabetes mellitus and sero prevalence for CMV. South Med J. 2005; 98(7): 686-692. DOI:10.1097/01.SMJ.0000163310.12516.2D

21. Chen S, Decraen AJ, Raz Y, Derhovanessian E, Vossen AC, westendrop RG, et al. Cytome galovirus seropositivity is associated with glucose regulation in the oldest old. Results from the leiden 85-plus study. Immunity. 2012; 8(9): 18-24 Immun Ageing. 2012; 9(1): 18. doi: 10.1186/1742-4933-9-18. 